\title{
EXAMINING WETHER PERSONAL CHARACTERISTICS IN SEVERE ASTHMA PATIENTS INCREASE THE PROBABILITY OF BEING INFECTED BY COVID-19
}

\author{
Roxana Farzanegan ${ }^{1}$, Mario Andújar Llamazares ${ }^{1}$, Alba Novales López ${ }^{1}$, Jose Vicente \\ Castelló Carrascosa ${ }^{1}$, María José Bueso Fabra ${ }^{1}$, María Cruz Torres Gorriz ${ }^{1}$, Raquel \\ Cervera Aznar ${ }^{1}$, Julián Borrás Cuartero ${ }^{1}$, Margarita Marín Royo ${ }^{1}$, and Ernesto Enrique ${ }^{1}$ \\ ${ }^{1}$ Castellon University General Hospital
}

August 3, 2020

\begin{abstract}
Background: The pandemic caused by Coronavirus disease 2019, has caused great impact worldwide. Risk factors for severe outcomes have been identified, but asthma seems not to be one of them. Objectives: Our principal purpose is to analyze personal characteristics in severe asthma patients, in treatment with monoclonal antibody, belonging to the Health Department of Castellon, in order to see if these variables affect the probability of being infected by SARS-Cov-2. Methods: This is an observational study. Patients recruited had severe asthma in treatment with monoclonal antibody. A questionnaire was elaborated. Aspects evaluated were: COVID-19 symptoms, asthma control, exposition to the disease, and lifestyle before the pandemic. Serological tests were done by using total SARS-Cov-2 antibody test. Results: 108 patients were enrolled in the study, of whom 106 patients were included. 11 patients declared suggestive COVID-19 symptoms. A total of 21 patients had a serology test done, giving positive results 2 of them. 27 patients needed medical attention, being asthma exacerbation the most common symptom. $71,7 \%$ of patients had a normal or high level of social activity before the pandemic. Statistic significance was achieved for medical assistance, asthma control and contact with SARS-Cov-2 positive patients. Conclusion: Personal external factors in severe asthma patients do not influence the probability of being affected by the disease. We can hypothesize that these patients do not have an increased susceptibility for being infected by the virus. Bad asthma control was the main reason for medical assistance during the pandemic.
\end{abstract}

Key words: Severe asthma. Monoclonal antibodies. Coronavirus disease 2019. INTRODUCTION

The pandemic caused by SARS-CoV-2, most commonly known as Coronavirus disease 2019 (COVID-19), is one of the most important challenges humanity is facing nowadays, pushing health systems around the world to maximum capacity, leading to the collapse in intensive care units [1].

Its clinical forms vary from asymptomatic to mild, moderate, and severe symptoms, leading to fatal events in many cases. One of the most common symptoms is the development of an acute respiratory disease, which can lead to respiratory or multi-organ failure [2].

Current research has identified, several risk factors for severe outcomes. The most important factors include old age, hypertension, diabetes, cardiovascular disease, tobacco exposure, malignancies, and immunosuppression [3]. Initially, asthma was thought to be a risk factor for SARS-CoV-2 infection, as COVID -19 primarily affects the respiratory system; surprisingly, many are the reports, and large case series published that remark the low prevalence of asthma among COVID -19 patients [4-8], including those admitted in the intensive care unit, who required mechanical ventilation (1.8\%) [9]. 
The main purpose of this study is to analyze the personal characteristics in severe asthma patients in treatment with monoclonal antibody (MAB), belonging to the Health Department of Castellon's University General Hospital, (Castellon, Spain), in order to see which behavioral and social circumstances obey patients, and if these variables affect in any way the probability of being infected by COVID-19 or not. Secondly, we wanted to investigate the prevalence of COVID-19 in these patients.

\section{METHODS}

\section{Data source}

This is an observational, cross-sectional study designed by the Allergy Department of Castellon's University General Hospital, Spain. Subjects recruited were patients with severe asthma in treatment with MAB, pertaining to the Departments of Allergy and/or Pneumology in our hospital (108 patients). A list of all patients was obtained by using the data base available in each department. Inclusion criteria: patients with severe asthma, in treatment with any of the MAB, approved for severe asthma treatment (omalizumab, mepolizumab, benralizumab or reslizumab), during 6 months or more and with a positive complementary study for asthma diagnosis (spirometry with positive bronchial dilatation, or positive methacholine test). Exclusion criteria: patients who had recently started biological treatment (i 6 months), or patients who had discontinued treatment by self-decision. The time span of analysis dates from $1^{\underline{0}}$ March to $30^{\circ}$ May 2020, corresponding to the months with most incidence of the disease in Spain.

In order to answer the principal objective, a questionnaire was developed with a total of 19 questions (Table 1) divided in 3 blocks. Block one corresponds to questions 1 to 4 , where patients were asked about COVID-19 symptoms, COVID-19 RT-PCR and serological tests results. Block two: questions 5 to 11 made reference to asthma control and treatment during the pandemic. Block Three: questions 12 to 19 analyzed possible exposition to the disease, and their lifestyle before the pandemic.

When referring to therapeutic adherence to base treatment (questions 5 and 10), Test of Adherence to Inhalers (TAI - 10 items) [10] was used. A result of 50 meant good adherence, between 46-49 meant intermedia adherence, and 45 or below, meant bad adherence. Subsequently, in order to analyze patients' asthma control, the Asthma control test (ACT) [11] was used. A result of 20 or more meant good asthma control, meanwhile, 19 or less, meant poor asthma control. When analyzing their daily activity before the pandemic (question 15), an active level of activity, was defined as, going out 7 days a week (for work, sport activities, social meetings, shopping, etc.); a normal level, 5 days a week, a moderate level, less than 5 days a week, and a low level of activity, less than 2 days a week. Questionnaires were completed either face-to-face or by telephone. Before filling in the questionnaire, oral consent was requested to each patient. Approval from the ethics committee was obtained.

Clinical data values analyzed for each patient (Table 2), were collected using the hospital's clinical network. Clinical values were chosen based on risk and protective factors described for coronavirus disease [12, 13]. Data registered included, sex, age, type of asthma, inhaled corticosteroid doses, oral corticosteroid treatment, and comorbidities. Significant clinical values for asthma syndrome were recorded: FEV1, association of nasal polyps, Samter's Triad, Allergic bronchopulmonary Aspergillosis (ABPA), and the need of medical attention or hospitalization in the last year, due to uncontrolled asthma. Once each variable was collected and analyzed, serological tests were performed at the hospital's laboratory, to patients who have had suggestive COVID-19 symptoms, by using total SARS-Cov-2 antibody test by immunochromatography (Wondfoß, Guangzhou Wondfo Biotech Co., Ltd. P.R. China). During the months of June and July, blood tests were carried out to patients, the day they came for their biological treatment administration.

\section{Statistical methods}

A descriptive analysis of the study variables was performed, to identify patients' personal and clinical characteristics, and their responses to the questionnaire. The qualitative variables are described using absolute frequencies and percentages. Quantitative variables are resumed through their media, median, first and third quartile, and typical deviation. 
To compare patients' responses to the questionnaire according to compatible symptoms of COVID-19 or a positive test result, contingency tables were built with the variables. The association between the qualitative values was evaluated throughout Fisher's exact test (with Montecarlo simulation of p-value in case of qualitative variables with more than two categories). The comparison of the quantitative variables was done using Mann-Whitney U test. Normalcy between the variables were contrasted using Shapiro-Wilk test. It is considered of significant relevance between variables, a signification level of 0.05 . The analysis were performed using R statistic software. (Version 4.0.0).

\section{RESULTS}

A total of 108 patients with severe asthma in treatment with MAB were enrolled, of whom only 106 patients were included in the study. Due to exclusion criteria, two patients were excluded: one case had started biological treatment two months ago, and the other case had discontinued biological treatment by selfdecision.

Descriptive analysis of patients' clinical characteristics are shown in Table 2.

When analyzing patients' responses to the questionnaire (Table 3), 11 patients (10.38\%) declared to have had suggestive COVID-19 symptoms. Most common symptoms between these patients were: cough ( 7 patients; $63 \%)$ and fever (7 patients; $63 \%$ ). Other less common symptoms referred were odynophagia (3 patients; $27.3 \%$ ), dyspnea (2 patients; $18.1 \%$ ), headache (1 patient; $9 \%$ ), and asthenia (1 patient; $9 \%$ ). No one needed hospitalization.

From the 106 patients included, 9 (8.49\%) had COVID-19 polymerase chain reaction test (RT-PCR) done at their ambulatory centre, being negative for the $9(100 \%)$ of them. From these 9 patients, only $2(22.2 \%)$ had referred suggestive COVID-19 symptoms; the other 9 patients with suggestive COVID-19 symptoms did not have RT-PCR done. In the case of serology test for COVID-19, $10(9.43 \%)$ of the 106 patients had the test done, only being positive for 2 of them (20\%), none of which corresponded to the 11 patients with suggestive COVID-19 symptoms. From these, only 1 patient had serology test done, which gave a negative result.

When asked about their mood (question 7), a stable mood and anxiety, were the most relevant answers. In reference to the need of medical ambulatory assistance during the confinement (question 8), a total of 27 patients referred they had needed medical attention, being the most common reason, asthma exacerbation symptoms (14 patients $(51,9 \%)$ ), from which 7 (25.9) corresponded to those who referred possible COVID19 symptoms. Other symptoms that motivated medical assistance where, chest pain, odynophagia, upper respiratory infection, herpes virus, rhinitis, urine infection and renal colic. No one needed hospitalization. In reference to the 2 patients with a positive result in the serology test, one had to receive medical ambulatory assistance due to unspecific chest pain, while the other did not experiment any symptoms nor needed medical attention.

Regarding direct exposition with a person positive for COVID-19 (question 13), 8 patients (7.55\%) declared that they had been in contact; from whom, $1(12,5 \%)$ corresponded to the patient with a positive serology test, who had experimented chest pain symptoms; 2 (25\%) corresponded to patients with possible COVID-19 symptoms, but with no RT-PCR or serology test done; and the other 5 patients $(62.5 \%)$ had no symptoms.

Questions 15 to 19 made reference to social and work activity. When analyzing these variables, it can be highlighted that $50.94 \%$ of the patients studied had assisted to crowded meetings weeks before the pandemic arrived to Spain. $71,7 \%$ of the patients had a normal or active level of activity. $72.64 \%$ have had contact with young children and/or adolescents, mainly their children or grandchildren; and $91.51 \%$ lived with more people at home, meaning that the risk of being infected by SARS-Cov-2 was not only conditioned by their own public exposition, but also by the exposition of people in direct contact with them. It draws the attention that during the period of confinement declared in Spain, from the 15 of March 2020, until the end of May, period in which the analysis was completed, $58.49 \%$ of the patients left their home for various reasons, with no effect on the number of positive cases.

Table 4 shows the clinical characteristics of the 2 patients with a positive serological test for COVID-19. From 
their questionnaire, it is worth outlining that Patient 1 needed medical assistance due to unspecific chest pain, and patient 2 did not have symptoms. Neither needed to use their short acting bronchodilator, nor needed hospitalization. Both referred good asthma control in the ACT test. None of them worked, however Patient 1 had an active level of activity, and patient 2 a moderate level. Both of them went out during the pandemic, more than 5 times per month.

Lastly, serological tests were performed by using total SARS-Cov-2 antibody test, in order to study the real prevalence of the disease between the patients who referred suggestive COVID-19 symptoms, and patients with asthma exacerbation symptoms, odynophagia or upper respiratory infection who had needed medical attention during the state of alarm, (a total of 21 patients). For all of them, test results were negative. Clinical characteristics and serological tests results for these patients are shown in Table 5.

When comparing patient's responses to the questionnaire, according to suggestive COVID-19 symptoms or a positive serological test result, statistical significance was achieved for questions shown in Table 6, which make reference to the need of medical assistance during the state of alarm, asthma control (ACT) and contact why positive COVID-19 patients. With these results we can state that patients with bad asthma control and/or contact with positive COVID-19 cases, have needed more medical assistance in comparison to the rest of the patients studied.

\section{DISCUSSION}

Coronavirus disease 2019 (COVID-19), has become in a short period of time, one of the worst infection disease ever known around the world, declaring a Public Health Emergency of International Concern. Spain has been one of the most severely affected countries in Europe. Data dated on the 6 of July 2020, declared 2.648.971 confirmed cases in all of Europe, 250.545 of which correspond to Spain. Castellon's Health Department attends a total of 283,021 people. From these, 927 (0.33\%) patients with COVID-19 have been detected until now. In our Hospital, a total of 234 patients required hospitalization due to COVID-19, of whom 34 (14.5\%) required hospitalization in the intensive care unit. The first hospitalization was reported on the 13 of March 2020. Out of the 234 patients, no one had asthma as comorbidity.

This study underlines that external factors surrounding asthma patients do not influence the probability of being affected by the disease. It is important to emphasize that most of severe asthma patients studied, comply with risk factors described for COVID-19 disease, without seeming to affect their susceptibility to the infection.

Moreover, it shows that a poor asthma control is the main reason that conditioned the need for medical assistance during the pandemic, highlighting that, the period of most impact in Spain coincided with pollination season, reason why allergic asthma patients might of have been less controlled.

When studying severe asthma patients in treatment with MAB, corresponding to our Medical Department, it is seen that none of them corresponded to any of the 234 patients hospitalized, suggesting a low prevalence of the disease in these patients. This same evidence has been reported by Haroun-Diaz et al in Madrid, Spain, where the disease has had a much greater impact. ${ }^{14}$ The main limitation of this study is that exact prevalence of the disease in these patients cannot be known, as most of the patients did not have a RT-PCR or serological test done; however taking into account that until June, diagnostic tests were only done to patients with moderate to severe symptoms who required hospitalization, exact prevalence of COVID-19 in our population is unknown. The next step is to perform total antibody serological test to the 106 patients, in order to determine exact prevalence, taking into consideration the high sensitivity of the test (86.43\%) and its high specificity $(99.57 \%)$.

In the case that severe asthma patients contracted the disease, this study suggests they would have shown very weak to no symptoms. The thesis is also supported by Haroun-Diaz et al [14]. Reasoning for this include a series of factors recently studied in the wake of COVID -19 pandemic. Speculations emphasize on type 2 immune response as a potential protective factor against COVID -19 [15]. Proinflammatory type I and III immune response, with the production of IFN, are the base for an antiviral response. Asthmatics have 
greater susceptibility to respiratory viral infections due to a defective production of IFNs in severe atopic patients $[16,17]$. However, in this case, some authors hypothesize that Th-2 dominant environment might be protective against COVID -19 as it may be able to downregulate the late phase of hyper-inflammation, responsible of tissue damage and cytokine storm [5, 18-20].

Treatment with inhaled corticoids in asthma patients seem also to be protective [2], as seen in in-vitro studies, where inhaled corticosteroids alone or in combination with bronchodilators were able to suppress coronavirus replication and cytokine production [21,22]. Michael et al. reported that inhaled corticosteroids reduce genes expression of viral membrane receptors (ACE2 and TMPRSS2) in asthmatic patients' sputum [23]. Angiotensin converting enzyme 2 (ACE2) and transmembrane protease serine 2 (TMPRSS2) are the receptors used by SARS-CoV-2 for viral infection [24]. The higher the ACE2 expression is, the greater the susceptibility to SARS-Cov [25]. Up regulation of ACE2 receptors gene expression is associated with smoking, diabetes and hypertension [26], while down regulation has been proved to be associated with respiratory allergy and controlled allergen exposures, being lower in those with both high levels of allergic sensitization and asthma [27]. Shi Wendan et al. found that combined allergies might reduce the destructive power of SARS-CoV-2, as COVID-19 patients with allergy, had less severe initial conditions and lower degree of lung lesions. At the same time, the interval of RT-PCR negativization was shorter in allergic patients [28].

Both theories above mentioned, are supported by the study's observations, as both patients with a positive serological test, had an eosinophilic asthma, and followed treatment with high doses of inhaled corticoids.

Eosinophils play an important role in the defense against virus [29]. Early observations described eosinopenia in hospitalized COVID-19 patients, and correlated it with more severe cases, however further studies suggested that eosinopenia may not be associated with a bad progression of the disease [30-33].

Currently, studies focusing on the pathway in which biologicals targeting type 2 disease, may affect the patient's response to COVID-19 is scarce. There is no evidence neither for a protective effect nor a negative effect of these biologicals regarding SARS-Cov-2 infection [34]. Further studies are needed in this regard.

To our knowledge, this is the first published study describing the external factors surrounding severe asthma patients and if these affect their susceptibility for the disease. The conclusions drawn from this study, underline personal and clinical factors in these patients are not risk factors, and do not influence the probability of being affected by the disease. Therefore, it can be hypothesized that severe asthma patients in treatment with MAB, do not have an increased susceptibility for being infected by the virus.

ACKNOWLEDGEMENTS: For the statistical analysis of the results, we appreciate the collaboration of Paqui Corpas Burgos (FISABIO).

DATA SHARING: The data that support the findings of this study are available from the corresponding author upon reasonable request.

\section{REFERENCES}

1. Vultaggio A, Agache I, A. Akdis C, Akdis M, Bavbek S, Bossios A et al. Considerations on Biologicals for Patients with allergic disease in times of the COVID-19 pandemic: an EAACI Statement. Allergy 2020 (in press).

2. Halpin D, Faner R, Sibila O, Badia JR, Agusti A. Do chronic respiratory diseases or their treatment affect the risk of SARS-CoV-2 infection? Lancet Respir Med. 2020 May; 8(5):436-8.

3. Wu Z, McGoogan JM. Characteristics of and Important Lessons From the Coronavirus Disease 2019 (COVID-19) Outbreak in China: Summary of a Report of 72314 Cases From the Chinese Center for Disease Control and Prevention. JAMA. 2020 April; 323(13):1239-42.

4. Zhang JJ, Dong X, Cao YY, Yuan YD, Yang YB, Yan YQ, et al. Clinical characteristics of 140 patients infected with SARS-CoV-2 in Wuhan, China. Allergy 2020;00:1-12.

5. Carli G, Cecchi L, Stebbing J, Parronchi P, Farsi A. Is asthma protective against COVID-19? Allergy 2020;00:1-3. 
6. Zhang JJ, Cao YY, Dong X, Wang BC, Liao MY, Lin J, et al. Distinct characteristics of COVID-19 patients with initial rRt-PCR-positive and rRt-PCR-negative results for SARS-CoV-2. Allergy 2020;00:1-4.

7. Dong X, Cao YY, Lu XX, Zhang JJ, Du H, Yan YQ, et al. Eleven faces of coronavirus disease 2019. Allergy 2020;00:1-11.

8. Johnston SL. Asthma and COVID-19: is asthma a risk factor for severe outcomes? Allergy 2020 (in press).

9. Avdeev S, Moiseev S, Brovko M, Yavorovskiy A, Umbetova K, Akulkina L, et al. Low prevalence of bronchial asthma and chronic obstructive lung disease among intensive care unit patients with COVID-19. Allergy 2020;00:1-3.

10. Plaza V, Fernandez-Rodriguez C, Melero C, Cosio BG, Entrenas LM, de Llano LP, et al. Validation of "Test of the Adherence to Inhalers" (TAI) for asthma and COPD patients. J Aerosol Med Pulm Dug Deliv 2016;29:142-52.

11. Nathan RA, Sorkness CA, Kosinski M, Schatz M, Li JT, Marcus P, et al. Development of the asthma control test: a survey for assessing asthma control test. J Allergy Clin Immunol 2004;113:59-65.

12. Jordan RE, Adab P, Cheng KK. Covid-19: risk factor for severe disease and death. BMJ 2020;368:m1198.

13. Li X, Xu S, Yu M, Wang K, Tao Y, Zhou Y, et al. Risk factors for severity and mortality in adult COVID-19 inpatients in Wuhan. J Allergy Clin Immunol 2020;146(1):110-8.

14. Haroun-Díaz E, Vázquez de la Torre M, Ruano FJ, Somoza Álvarez ML, Pérez Alzate D, López González P, et al. Severe asthma during the COVID-19 pandemic: Clinical observations. J Allergy Clin Immunol Pract 2020 (in press).

15. Liu S, Zhi Y, Ying S. COVID-19 and Asthma: Reflection During the Pandemic. Clin Rev Allergy Immunol. 2020

16. Gonzales-van Horn SR, Farrar JD. Interferon at the crossroads of allergy and viral infections. J Leukoc Biol. 2015 Aug;98(2):185-94.

17. Lebre MC, van Capel TM, Bos JD, Knol EF, Kapsenberg ML, de Jong EC. Aberrant function of peripheral blood myeloid and plasmacytoid dendritic cells in atopic dermatitis patients. J Allergy Clin Immunol. 2008;122(5):969-76.

18. Richardson PJ, Corbellino M, Stebbing J. Baricitinib for COVID-19: a suitable treatment? -Authors' reply. Lancet Infect Dis. 2020 Apr 3.

19. Cameron MJ, Ran L, Xu L, Danesh A, Bermejo-Martin JF, Cameron CM, et al. Interferon-mediated immunopathological events are associated with atypical innate and adaptive immune responses in patients with severe acute respiratory syndrome. J Virol. 2007 Aug;81(16):8692-706.

20. Channappanavar R, Fehr AR, Vijay R, Mack M, Zhao J, Meyerholz DK, et al. Dysregulated Type I Interferon and Inflammatory Monocyte-Macrophage Responses Cause Lethal Pneumonia in SARSCoVInfected Mice. Cell Host Microbe. 2016 Feb 10;19(2):181-93.

21. Yamaya M, Nishimura H, Deng X, Sugawara M, Watanabe O, Nomura K, et al. Inhibitory effects of glycopyrronium, formoterol, and budesonide on coronavirus $\mathrm{HCoV}-229 \mathrm{E}$ replication and cytokine production by primary cultures of human nasal and tracheal epithelial cells. Respir Investig 2020 May; $58(3): 155-68$.

22. Matsuyama S, Kawase M, Nao N, Shirato K, Ujike M, Kamitani W, et al. The inhaled corticosteroid ciclesonide blocks coronavirus RNA replication by targeting viral NSP15. bioRxiv 2020 (in press).

23. Peters MC, Sajuthi S, Deford P, Christenson S, Rios CL, Montgomery MT, et al. COVID-19 related genes in sputum cells in asthma: relationship to demographic features and corticosteroids. Am J Respir Crit Care Med 2020;202(1):83-90.

24. Zhou P, Yang XL, Wang XG, Hu B, Zhang L, Zhang W, et al. A pneumonia outbreak associated with a new coronavirus of probable bat origin. Nature 2020;579(7798):270-3.

25. Jia HP, Look DC, Shi L, Hickey M, Pewe L, Netland J, et al. ACE2 receptor expression and severe acute respiratory syndrome coronavirus infection depend on differentiation of human airway epithelia. J Virol. 2005;79(23):14614-21. 
26. Brake SJ, Barnsley K, Lu W, McAlinden KD, Eapen MS, Sohal SS. Smoking Upregulates AngiotensinConverting Enzyme-2 Receptor: A Potential Adhesion Site for Novel Coronavirus SARS-CoV-2 (Covid19). Journal of Clinical Medicine 2020;9(3).

27. Jackson DJ, Busse WW, Bacharier LB, Kattan M, O'Connor GT, Wood RA, et al. Association of respiratory allergy, asthma and expression of the SARS-CoV-2 receptor, ACE2. J Allergy Clin Immunol 2020 jul; 146(1):203-6.

28. Shi W, Gao Z, Ding Y, Zhu T, Zhang W, Xu Y, et al. Clinical characteristics of COVID-19 patients combined with allergy. Allergy 2020;00:1-4.

29. Rodrigo-Munoz JM, Sastre B, Canas JA, Gil-Martinez M, Redondo N, del Pozo V· Eosinophil Response Against Classical and Emerging Respiratory Viruses: COVID-19. J Investig Allergol Clin Immunol 2021; Vol. 31(2) (in press).

30. Huang C, Wang Y, Li X, Ren L, Zhao J, Hu Y, et al. Clinical features of patients infected with 2019 novel coronavirus in Wuhan, China. Lancet. 2020;395(10223):497-506.

31. Lippi G, Henry BM. Eosinophil count in severe coronavirus disease 2019. QJM 2020 Jul;113(7):511-2.

32. Lindsley AW, Schwartz JT, Rothenberg ME. Eosinophil responses during COVID-19 infections and coronavirus vaccination. J Allergy Clin Immunol 2020;146(1):1-7.

33. Jesenak M, Banovcin P, Diamant Z. COVID-19, chronic inflammatory respiratory diseases and eosinophils - Observations from reported clinical case series. Allergy 2020. (in press).

34. Riggioni C, Comberiati P, Giovannini M, Agache I, Akdis M, Alves-Correia M, el al. A compendium answering 150 questions on COVID-19 and SARS-CoV-2. Allergy 2020. (in press).

\section{TABLES}

Table 1. Questionnaire

\section{QUESTIONNAIRE}

Have you had symptoms compatible with Covid-19?

1.2. If responded yes: which ones?

Have you had a covid-19 RT-PCR test done?

If responded yes: what was the result?

Have you had a covid-19 serology test done?

If responded yes: what was the result?

Have you been hospitalized do to covid-19?

What has been your therapeutic adherence to your base treatment during the state of alarm*?

Have you followed treatment the same way as before the pandemic?

How did you feel animically during the first months of the state of alarm?

Have you needed medical assistance during the state of alarm?

8.1. If responded yes: what was the reason why?

8.2. If responded yes: did you attend a medical centre?

8.3. Did doctors resolve the problem?

8.4. Where you satisfied with the attention given?

Did you need to use your short-acting bronchodilator during the state of alarm?

How controlled has your asthma been during this month?

Are you smoker?

11.1. If responded yes: did you stop smoking in the wake of the pandemic?

Do you know any person who has given positive for covid-19 test?

Have you been in contact with someone positive for covid-19?

Where you in any meeting or social event with more than 10 people, before the state of alarm began?

What was your level of activity before the state of alarm began?

Work activity

Where you in contact with children and/or adolescents before the state of alarm?

Do you live with more people at home? 


\section{QUESTIONNAIRE}

Have you left your home during the state of alarm?

19.1. If responded yes: with what frequency?

19.2. What for?: Multiple choice.

*State of alarm declared by the Spanish Government the $15^{\text {th }}$ of March of 2020, in response to COVID-19 pandemic, in order to try to restore the order within the country, adopting strict measures of social distance and confinement.

Table 2. Patients clinical characteristics description

\begin{tabular}{|c|c|c|}
\hline Variable & Categories & $N=106(100 \%)$ \\
\hline & & $\begin{array}{l}\text { Media (Standard } \\
\text { Deviation }) / \mathbf{n}(\%) \text { Median } \\
\left(1^{\mathbf{o}}, 3^{\mathbf{o}} \text { Quartile). }\right.\end{array}$ \\
\hline Gender & Male Female & $28(26.42 \%) 78(73.58 \%)$ \\
\hline Age (Years) & $15-3940-4950-5960-79$ ро 80 & $\begin{array}{l}9(8.49 \%) 10(9.43 \%) 30(28.3 \%) \\
52(49.06 \%) 5(4.72 \%)\end{array}$ \\
\hline Samter's Triad & Yes No & $14(13.21 \%) 92(86.79 \%)$ \\
\hline Nasal Polyps & Yes No & $22(20.75 \%) 84(79.25 \%)$ \\
\hline ABPA & Yes No & $4(3.77 \%) 102(96.23 \%)$ \\
\hline Type of Asthma & $\begin{array}{l}\text { Allergic Asthma Nonallergic } \\
\text { asthma Missing variables }\end{array}$ & $52(50 \%) 52(50 \%) 2(1.89 \%)$ \\
\hline Inhaled corticosteroid dose* & $\begin{array}{l}\text { Low Medium High Missing } \\
\text { variables }\end{array}$ & $\begin{array}{l}29(27.62 \%) 44(41.9 \%) 32 \\
(30.48 \%) 1(0.94 \%)\end{array}$ \\
\hline Oral corticosteroid base treatment & Yes No & $4(3.77 \%) 102(96.23 \%)$ \\
\hline Last FEV1 registered & $\begin{array}{l}{[?] 50 \% 51-59 \% 60-80 \%} \\
81-89 \%[?] 90 \% \text { Missing } \\
\text { variables }\end{array}$ & $\begin{array}{l}7(7 \%) 6(6 \%) 35(35 \%) 14(14 \%) \\
38(38 \%) 6(6 \%)\end{array}$ \\
\hline $\begin{array}{l}\text { Comorbidities (Age, DM, HT, } \\
\text { DLP, Obesity, SAHS, } \\
\text { Immunodeficiencies) }\end{array}$ & $\begin{array}{l}\text { None One Two Three or } \\
\text { more }\end{array}$ & $\begin{array}{l}14(13.21 \%) 23(21.7 \%) 24 \\
(22.64 \%) 45(42.45 \%)\end{array}$ \\
\hline $\begin{array}{l}\text { Need of medical assistance due to } \\
\text { asthma symptoms during the last } \\
\text { year }\end{array}$ & Yes No & $44(41.51 \%) 62(58.49 \%)$ \\
\hline $\begin{array}{l}\text { Need of medical hospitalization } \\
\text { due to asthma symptoms during } \\
\text { the last year }\end{array}$ & Yes No & $6(5.66 \%) 100(94.34 \%)$ \\
\hline
\end{tabular}

ABPA: Allergic bronchopulmonary Aspergillosis; DM: Diabetes Mellitus; HT: Hypertension; DLP: Dyslipidemia; SAHS: Sleep apnea/hyponea syndrome

*GEMA 5.0 (http://gemasma.com)

Table 3. Description of patients answers to the questionnaire

\begin{tabular}{lll}
\hline QUESTIONNAIRE & ANSWERS & Variable N=106 (100\%) \\
\hline $\begin{array}{l}\text { Have you had symptoms } \\
\text { compatible with Covid-19? }\end{array}$ & Yes No & $11(10.38 \%) 95(89.62 \%)$
\end{tabular}




\begin{tabular}{|c|c|c|}
\hline QUESTIONNAIRE & ANSWERS & Variable $N=106(100 \%)$ \\
\hline $\begin{array}{l}\text { 1.2. If responded yes: } \\
\text { which ones? }\end{array}$ & Open answer & \\
\hline $\begin{array}{l}\text { Have you had a covid-19 } \\
\text { RT-PCR test done? }\end{array}$ & Yes No & $9(8.49 \%) 97(91.51 \%)$ \\
\hline $\begin{array}{l}\text { If responded yes: what was } \\
\text { the result? }\end{array}$ & Positive Negative & $0(0 \%) 9(100 \%)$ \\
\hline $\begin{array}{l}\text { Do you have covid-19 } \\
\text { serology test done? }\end{array}$ & Yes No & $10(9.43 \%) 96(90.57 \%)$ \\
\hline $\begin{array}{l}\text { If responded yes: what was } \\
\text { the result? }\end{array}$ & Positive Negative & $2(20 \%) 8(80 \%)$ \\
\hline $\begin{array}{l}\text { Have you been hospitalized } \\
\text { do to covid-19? }\end{array}$ & Yes No & $0(0 \%) 106(100 \%)$ \\
\hline $\begin{array}{l}\text { What has been your } \\
\text { therapeutic adherence to } \\
\text { your base treatment during } \\
\text { the state of alarm? }\end{array}$ & $\begin{array}{l}\text { TAI result* Good Intermedia } \\
\text { Bad }\end{array}$ & $\begin{array}{l}66(62.26 \%) 21(19.81 \%) 19 \\
(17.92 \%)\end{array}$ \\
\hline $\begin{array}{l}\text { Have you followed } \\
\text { treatment the same way as } \\
\text { before the pandemic? }\end{array}$ & Yes No & $93(87.74 \%) 13(12.26 \%)$ \\
\hline $\begin{array}{l}\text { How did you feel animically } \\
\text { during the first months of } \\
\text { the state of alarm? } * * *\end{array}$ & Good Anxious Depressive & $\begin{array}{l}64(60.38 \%) 40(37.74 \%) 25 \\
(23.58 \%)\end{array}$ \\
\hline $\begin{array}{l}\text { Have you needed medical } \\
\text { assistance during the state } \\
\text { of alarm? }\end{array}$ & Yes No & $27(25.47 \%) 79(74.53 \%)$ \\
\hline $\begin{array}{l}\text { 8.1.If responded yes: what } \\
\text { was the reason why? }\end{array}$ & Open answer & \\
\hline $\begin{array}{l}\text { 8.2. If responded yes: did } \\
\text { you attend a medical centre? }\end{array}$ & a. Yes b. No & $13(48.15 \%) 14(51.85 \%)$ \\
\hline $\begin{array}{l}\text { 8.3. Did doctors resolve the } \\
\text { problem? }\end{array}$ & a. Yes b. No & $27(100 \%) 0(0 \%)$ \\
\hline $\begin{array}{l}\text { 8.4. Where you satisfied with } \\
\text { the attention given? }\end{array}$ & a. Yes b. No & $25(92.59 \%) 2(7.41 \%)$ \\
\hline $\begin{array}{l}\text { Did you need to use your } \\
\text { short-acting bronchodilator } \\
\text { during the state of alarm? }\end{array}$ & a. Yes b. No & $45(42.45 \%) 61(57.55 \%)$ \\
\hline $\begin{array}{l}\text { How controlled has your } \\
\text { asthma been during this } \\
\text { month? }\end{array}$ & $\begin{array}{l}\text { ACT result** No control } \\
\text { Control }\end{array}$ & $33(31.13 \%) 73$ (68.87\%) \\
\hline Are you smoker? & a. Yes b. No & $4(3.77 \%) 102(96.23 \%)$ \\
\hline $\begin{array}{l}\text { 11.1. If responded yes: did } \\
\text { you stop smoking in the wake } \\
\text { of the pandemic? }\end{array}$ & a. Yes b. No & $1(25 \%) 3(75 \%)$ \\
\hline $\begin{array}{l}\text { Do you know any person } \\
\text { who has given positive for } \\
\text { covid-19 test? }\end{array}$ & a. Yes b. No & $12(11.32 \%) 94(88.68 \%)$ \\
\hline Have you been in contact & a. Yes b. No & $8(7.55 \%) 98(92.45 \%)$ \\
\hline
\end{tabular}
covid-19? 


\begin{tabular}{|c|c|c|}
\hline QUESTIONNAIRE & ANSWERS & Variable $N=106(100 \%)$ \\
\hline $\begin{array}{l}\text { Where you in any meeting } \\
\text { or social event with more } \\
\text { than } 10 \text { people, before the } \\
\text { state of alarm began? }\end{array}$ & a. Yes b. No & $54(50.94 \%) 52(49.06 \%)$ \\
\hline $\begin{array}{l}\text { What was your level of } \\
\text { activity before the state of } \\
\text { alarm began? }\end{array}$ & Active Normal Moderate Low & $\begin{array}{l}63(59.44 \%) 13(12.26 \%) 13 \\
(12.26 \%) 17(16.04 \%)\end{array}$ \\
\hline Work activity & $\begin{array}{l}\text { Face to the public Not face to } \\
\text { the public Do not work }\end{array}$ & $\begin{array}{l}21(19.81 \%) 22(20.75 \%) 63 \\
(59.43 \%)\end{array}$ \\
\hline $\begin{array}{l}\text { Where you in contact with } \\
\text { children and/or adolescents } \\
\text { before the state of alarm? }\end{array}$ & a. Yes b. No & $77(72.64 \%) 29(27.36 \%)$ \\
\hline $\begin{array}{l}\text { Do you live with more } \\
\text { people at home? }\end{array}$ & a. Yes b. No & $97(91.51 \%) 9(8.49 \%)$ \\
\hline $\begin{array}{l}\text { Have you left your home } \\
\text { during the state of alarm? }\end{array}$ & a. Yes b. No & $62(58.49 \%) 44(41.51 \%)$ \\
\hline $\begin{array}{l}\text { 19.1. If responded yes: with } \\
\text { what frequency? }\end{array}$ & $\begin{array}{l}\text { a. [?] } 2 \text { days } / \text { month } b .3-4 \\
\text { days } / \text { month } c .[?] 5 \\
\text { days } / \text { month }\end{array}$ & $\begin{array}{l}13(20.97 \%) 7(11.29 \%) 42 \\
(67.74 \%)\end{array}$ \\
\hline 19.2. What for: & $\begin{array}{l}\text { a. Going to work b. For buying } \\
\text { essential needs c. Going for a } \\
\text { walk with the dog d. Others }\end{array}$ & $\begin{array}{l}19(17.92 \%) 38(35.85 \%) 4 \\
(3.77 \%) 22(20.75 \%)\end{array}$ \\
\hline
\end{tabular}

* TAI: Test of adherence to inhalators. ${ }^{* *} \mathrm{ACT}$ : Asthma control test.

Table 4. Individual characteristics of the 2 patients with positive serologic test for COVID-19

\begin{tabular}{lll}
\hline Patient & Patient 1 & Patient 2 \\
\hline Gender & Female & Male \\
Age & $\mathbf{6 0 - 7 9}$ & $\mathbf{6 0 - 7 9}$ \\
Samter's Triad & No & Yes \\
Nasal Polyps & No & Yes \\
ABPA & No & No \\
Type of asthma & Non allergic & Non allergic \\
Inhaled corticoid dose & High & High \\
Oral corticoids & No & No \\
Last FEV1 registered & $\mathbf{9 0}>\%$ & $\mathbf{9 0}>\mathbf{\%}$ \\
Comorbidities & One & Three \\
Medical assistance during last year & Yes & Yes \\
Need of medical hospitalization during last year & No & No \\
ACT May 2020 & Control & Control \\
\hline
\end{tabular}

Table 5. Individual clinical characteristics of the 21 patients with suggestive COVID-19 symptoms and/or asthma exacerbation, and their serological tests results.

\begin{tabular}{lllllllllll}
\hline & Patient & Patient & Patient & Patient & Patient & Patient & Patient & Patient & Patient & Patient \\
Patient & 1 & 2 & 3 & 4 & 5 & 6 & 7 & 8 & 9 & 10 \\
\hline Gender & Female & Female & Male & Female & Female & Female & Female & Female & Female & Female
\end{tabular}




\begin{tabular}{|c|c|c|c|c|c|c|c|c|c|c|}
\hline Patient & $\begin{array}{l}\text { Patient } \\
1\end{array}$ & $\begin{array}{l}\text { Patient } \\
2\end{array}$ & $\begin{array}{l}\text { Patient } \\
3\end{array}$ & $\begin{array}{l}\text { Patient } \\
4\end{array}$ & $\begin{array}{l}\text { Patient } \\
5\end{array}$ & $\begin{array}{l}\text { Patient } \\
6\end{array}$ & $\begin{array}{l}\text { Patient } \\
7\end{array}$ & $\begin{array}{l}\text { Patient } \\
8\end{array}$ & $\begin{array}{l}\text { Patient } \\
9\end{array}$ & $\begin{array}{l}\text { Patient } \\
10\end{array}$ \\
\hline$\overline{\text { Age }}$ & $60-79$ & $40-49$ & 50-59 & $60-79$ & $60-79$ & $60-79$ & 15-39 & $50-59$ & $60-79$ & $60-79$ \\
\hline $\begin{array}{l}\text { Samter's } \\
\text { Triad }\end{array}$ & No & No & Yes & No & No & No & No & No & No & No \\
\hline $\begin{array}{l}\text { Nasal } \\
\text { Polyps }\end{array}$ & No & No & Yes & No & No & No & No & No & No & No \\
\hline $\mathrm{ABPA}$ & No & No & No & No & No & No & No & No & No & No \\
\hline $\begin{array}{l}\text { Type } \\
\text { of } \\
\text { asthma }\end{array}$ & $\begin{array}{l}\text { Non } \\
\text { aller- } \\
\text { gic }\end{array}$ & Allergic & Allergic & $\begin{array}{l}\text { Non } \\
\text { aller- } \\
\text { gic }\end{array}$ & $\begin{array}{l}\text { Non } \\
\text { aller- } \\
\text { gic }\end{array}$ & Allergic & Allergic & Allergic & Allergic & Allergic \\
\hline $\begin{array}{l}\text { Inhaled } \\
\text { corti- } \\
\text { coid } \\
\text { dose }\end{array}$ & Medium & High & High & Medium & High & High & Low & Medium & Medium & Medium \\
\hline $\begin{array}{l}\text { Oral } \\
\text { corticoids }\end{array}$ & Yes & No & No & No & No & No & No & No & No & No \\
\hline $\begin{array}{l}\text { Last } \\
\text { FEV1 } \\
\text { registered }\end{array}$ & $90>\%$ & $\begin{array}{l}51- \\
59 \%\end{array}$ & $\begin{array}{l}81- \\
89 \%\end{array}$ & $\begin{array}{l}60- \\
80 \%\end{array}$ & $\begin{array}{l}51- \\
59 \%\end{array}$ & $\begin{array}{l}60- \\
80 \%\end{array}$ & $90>\%$ & $\begin{array}{l}60- \\
80 \%\end{array}$ & $\begin{array}{l}60- \\
80 \%\end{array}$ & - \\
\hline Comorbidit & t'Eswo & None & Three & Three & Three & Three & None & Three & Three & Three \\
\hline $\begin{array}{l}\text { Medical } \\
\text { assis- } \\
\text { tance } \\
\text { dur- } \\
\text { ing } \\
\text { last } \\
\text { year }\end{array}$ & No & Yes & Yes & No & Yes & Yes & No & Yes & Yes & Yes \\
\hline $\begin{array}{l}\text { Medical } \\
\text { hospi- } \\
\text { taliza- } \\
\text { tion } \\
\text { dur- } \\
\text { ing } \\
\text { last } \\
\text { year }\end{array}$ & No & No & No & No & No & No & No & No & No & No \\
\hline $\begin{array}{l}\text { ACT } \\
\text { May } \\
2020\end{array}$ & Control & $\begin{array}{l}\text { No } \\
\text { Con- } \\
\text { trol }\end{array}$ & $\begin{array}{l}\text { No } \\
\text { Con- } \\
\text { trol }\end{array}$ & Control & Control & Control & Control & $\begin{array}{l}\text { No } \\
\text { Con- } \\
\text { trol }\end{array}$ & Control & $\begin{array}{l}\text { No } \\
\text { Con- } \\
\text { trol }\end{array}$ \\
\hline $\begin{array}{l}\text { Serological } \\
\text { test }\end{array}$ & Negative & Negative & Negative & Negative & Negative & Negative & Negative & Negative & Negative & Negati \\
\hline
\end{tabular}

\begin{tabular}{llllllllll}
\hline & Patient & Patient & Patient & Patient & Patient & Patient & Patient & Patient & Patient \\
Patient & 12 & 13 & 14 & 15 & 16 & 17 & 18 & 19 & 20 \\
\hline Gender & Female & Female & Female & Female & Female & Female & Female & Female & Female \\
Age & $\mathbf{6 0 - 7 9}$ & $\mathbf{6 0 - 7 9}$ & $\mathbf{6 0 - 7 9}$ & $\mathbf{6 0 - 7 9}$ & $\mathbf{6 0 - 7 9}$ & $\mathbf{5 0 - 5 9}$ & $\mathbf{6 0 - 7 9}$ & $\mathbf{6 0 - 7 9}$ & $\mathbf{5 0 - 5 9}$ \\
Samter's & No & No & No & No & No & No & No & No & No \\
Triad & & & & & & & & No \\
Nasal & No & No & No & Yes & No & No & No & No & Yes \\
Polyps & & & & & & & & &
\end{tabular}




\begin{tabular}{|c|c|c|c|c|c|c|c|c|c|}
\hline Patient & $\begin{array}{l}\text { Patient } \\
12\end{array}$ & $\begin{array}{l}\text { Patient } \\
13\end{array}$ & $\begin{array}{l}\text { Patient } \\
14\end{array}$ & $\begin{array}{l}\text { Patient } \\
15\end{array}$ & $\begin{array}{l}\text { Patient } \\
16\end{array}$ & $\begin{array}{l}\text { Patient } \\
17\end{array}$ & $\begin{array}{l}\text { Patient } \\
18\end{array}$ & $\begin{array}{l}\text { Patient } \\
19\end{array}$ & $\begin{array}{l}\text { Patient } \\
20\end{array}$ \\
\hline$\overline{\mathrm{ABPA}}$ & No & No & No & No & No & No & No & No & No \\
\hline $\begin{array}{l}\text { Type } \\
\text { of } \\
\text { asthma }\end{array}$ & $\begin{array}{l}\text { Non } \\
\text { aller- } \\
\text { gic }\end{array}$ & $\begin{array}{l}\text { Non } \\
\text { aller- } \\
\text { gic }\end{array}$ & $\begin{array}{l}\text { Non } \\
\text { aller- } \\
\text { gic }\end{array}$ & $\begin{array}{l}\text { Non } \\
\text { aller- } \\
\text { gic }\end{array}$ & $\begin{array}{l}\text { Non } \\
\text { aller- } \\
\text { gic }\end{array}$ & Allergic & $\begin{array}{l}\text { Non } \\
\text { aller- } \\
\text { gic }\end{array}$ & $\begin{array}{l}\text { Non } \\
\text { aller- } \\
\text { gic }\end{array}$ & $\begin{array}{l}\text { Non } \\
\text { aller- } \\
\text { gic }\end{array}$ \\
\hline $\begin{array}{l}\text { Inhaled } \\
\text { corti- } \\
\text { coid } \\
\text { dose }\end{array}$ & Medium & Low & Medium & Medium & Medium & Medium & High & High & Medium \\
\hline $\begin{array}{l}\text { Oral } \\
\text { corticoids }\end{array}$ & No & No & No & No & No & No & No & No & No \\
\hline $\begin{array}{l}\text { Last } \\
\text { FEV1 } \\
\text { registered }\end{array}$ & $\begin{array}{l}60- \\
80 \%\end{array}$ & $90>\%$ & $90>\%$ & $\begin{array}{l}60- \\
80 \%\end{array}$ & $\begin{array}{l}81- \\
89 \%\end{array}$ & $\begin{array}{l}60- \\
80 \%\end{array}$ & $90>\%$ & $\begin{array}{l}60- \\
80 \%\end{array}$ & $90>\%$ \\
\hline Comorbiditi & ieEhree & Three & Two & Three & Three & Three & Three & Two & Two \\
\hline $\begin{array}{l}\text { Medical } \\
\text { assis- } \\
\text { tance } \\
\text { during } \\
\text { last } \\
\text { year }\end{array}$ & No & No & Yes & No & Yes & Yes & Yes & Yes & Yes \\
\hline $\begin{array}{l}\text { Medical } \\
\text { hospi- } \\
\text { taliza- } \\
\text { tion } \\
\text { during } \\
\text { last } \\
\text { year }\end{array}$ & No & No & No & No & No & No & No & No & No \\
\hline $\begin{array}{l}\text { ACT } \\
\text { May } 2020\end{array}$ & $\begin{array}{l}\text { No } \\
\text { Control }\end{array}$ & Control & Control & Control & $\begin{array}{l}\text { No } \\
\text { Control }\end{array}$ & $\begin{array}{l}\text { No } \\
\text { Control }\end{array}$ & Control & $\begin{array}{l}\text { No } \\
\text { Control }\end{array}$ & Control \\
\hline $\begin{array}{l}\text { Serological } \\
\text { test }\end{array}$ & Negative & Negative & Negative & Negative & Negative & Negative & Negative & Negative & Negative \\
\hline
\end{tabular}

Table 6. Comparation of patient's response to the questionnaire according to compatible COVID-19 symptoms or a positive test result, with statistical significance.

\begin{tabular}{|c|c|c|c|}
\hline & $\begin{array}{l}\text { Compatible } \\
\text { symptoms with } \\
\text { covid-19 or positive } \\
\text { serology test }\end{array}$ & $\begin{array}{l}\text { Compatible } \\
\text { symptoms with } \\
\text { covid-19 or positive } \\
\text { serology test }\end{array}$ & \\
\hline Variable & $\begin{array}{l}\text { No } \\
\mathbf{9 3}(\mathbf{8 7 . 7 4 \%}) \\
\text { Media (Standard } \\
\text { deviation) } / \mathrm{n}(\%) \\
\text { Median (1 } \text { er }^{\text {er }} \\
\text { Quartile) }\end{array}$ & $\begin{array}{l}\text { Yes } \\
\mathbf{1 3}(\mathbf{1 2 . 2 6 \%}) \\
\text { Media (Standard } \\
\text { deviation) } / \mathrm{n}(\%) \\
\text { Median }\left(1^{\mathrm{er}}, 3^{\text {er }}\right. \\
\text { Quartile) }\end{array}$ & $\mathrm{P}$-value \\
\hline
\end{tabular}




\begin{tabular}{llll}
\hline & $\begin{array}{l}\text { Compatible } \\
\text { symptoms with } \\
\text { covid-19 or positive } \\
\text { serology test }\end{array}$ & $\begin{array}{l}\text { Compatible } \\
\text { symptoms with } \\
\text { covid-19 or positive } \\
\text { serology test }\end{array}$ & \\
\hline $\begin{array}{l}\text { Question 8. Have you } \\
\text { needed medical }\end{array}$ & & & $<0.001^{*}$ \\
$\begin{array}{l}\text { assistance during the } \\
\text { state of alarm? }\end{array}$ & $76(81.72 \%)$ & $3(23.08 \%)$ & \\
$\begin{array}{l}\text { No } \\
\text { Yes }\end{array}$ & $17(18.28 \%)$ & $10(76.92 \%)$ & 0.0551 \\
$\begin{array}{l}\text { Question 10. ACT's } \\
\text { result }\end{array}$ & $24(26.37 \%)$ & $7(53.85 \%)$ & \\
$\begin{array}{l}\text { No control } \\
\text { Control }\end{array}$ & $67(73.63 \%)$ & $6(46.15 \%)$ & \\
$\begin{array}{l}\text { Yes } \\
\text { Question 13. Have }\end{array}$ & $10(10.75 \%)$ & $2(15.38 \%)$ & \\
you been in contact & & & \\
with someone & & & \\
positive for & & & \\
covid-19? & & $10(76.92 \%)$ & \\
No & & $3(23.08 \%)$ & \\
Yes & $88(94.62 \%)$ & & \\
\hline
\end{tabular}

